\title{
Cytoarchitectural Variations in the Ovary, Oviduct and Uterus Following Intra-Gastric Gavages of Abrus precatorius Linn in Albino Rats
}

\author{
Variaciones Citoarquitectónicas en el Ovario, Oviducto y Útero Después \\ del Gavage Intragástrico de Abrus precatorius Linn en Ratas Albinas
}

Ini-Ibehe Essien Okoko \& Oshiozokhai Eboetse Yama

OKOKO, I. E. \& YAMA, O. E. Cytoarchitectural variations in the ovary, oviduct and uterus following intra-gastric gavages of Abrus precatorius Linn in albino rats. Int. J. Morphol., 29(4):1408-1413, 2011.

SUMMARY: In developing countries, herbal medicines have continued to remain significant and readily patronized. Numerous plants have been used historically to reduce fertility and modern scientific research has confirmed antifertility effect in some of the herbs tested. To investigate the effects of Abrus precatorius $(A P)$ on the histology of the ovary, oviduct and uterus of female Sprague-Dawley (S-D) rat. A total of 40, 6-8 week old 4-day cycling female S-D rats were used. They were divided into the treatment, control and reversibility groups. The treatment and reversibility groups were fed oral AP seed extract ( $50 \mathrm{mg} / \mathrm{kg} \mathrm{b.w})$ for 32 days. A fraction of the rats in reversibility group was treated with distilled water for another 32 days. The control group were used to compare events in the other groups. At the end of the experimental durations animals were sacrificed under light chloroform anesthesia. Their ovaries, uteri and oviducts harvested for microscopic studies. Comparing the control histological sections to the treated groups: the ovaries showed decreased size, large follicular distension and extensive stromal necrosis with compromised cellularity. The uterine tubes revealed appreciable mucosal reduction. The uteri exhibited reduction in the layer of endometrial thickness. On the other hand sections in reversal experimental rats were comparable to control. The rats treated with $A P$ seed extract at dose $50 \mathrm{mg} / \mathrm{kg}$ b.w induced reversible alterations in ovaries, uterine and uteri in S-D.

KEY WORDS: Abrus precatorius; Sprague-Dawley rat; Ovaries; Uteri; Oviducts.

\section{INTRODUCTION}

The plant Abrus precatorius $(A P)$ has not been spared by investigators in the quest for indigenous plants with potentially contraceptive effects and having minimal adverse effects. Much of the work on it has been restricted to its antifertility effect in males (Sinha, 1990; Sinha \& Mathur 1990; Ratnasooriya et al., 1991).

All parts of the plant have been used for several purposes; ranging from the general to its pharmacologic uses. The seeds of AP also called, crab's eyes are often used as beads and in the manufacture of percussion instruments. One of the main reasons it was introduced worldwide was because the brightly coloured seeds were strung for necklaces and rosaries (Armstrong, 2000). The leaves and seeds of Abrus precatorius are nutritious. The seeds are considered to be an abortifacient, aphrodisiac, antimicrobial, to cure snake bite, cancer among others (Nath et al., 1992; Taylor, 2002; Deepak, 2003; Limmatvapirat et al., 2004).

Boiled seeds are eaten by the residents of the Andaman Islands in India (Rajaram \& Janardhanan, 1992). Ironically the most poisonous part of $A P$ is the seed rich in toxic proteins, the main one being abrin (Olsnes, 2004). Abrin is most toxic when inhaled or injected but less so when ingested. Intact seeds often pass through the gastrointestinal tract without harm while those damaged cause harm (Fernando, 2001). Human data reveals that one seed (0.11 microgramme/kg body weight) well masticated can cause fatal poisoning both in adults and children (Budavari, 1989).

Surprisingly, despite several claims of its efficacy by end-users, no long term clinical or toxicity studies have been 
reported on the antifertility effect of $A P$ in females. Although in our previous work (Okoko et al., 2011) we established that $A P$ seeds can reversibly disrupt estrous cycle pattern and also has anti ovulatory properties in cyclic female Sprague Dawley rats. We also demonstrated its abortifacient properties. However in the rationale of this present study is to further extend investigation of this plant in the light of its effect on ovaries, uterus and oviducts.

\section{MATERIAL AND METHOD}

Animals. Healthy female Sprague-Dawley (S-D) rats totalling 40 were randomized in mesh metal cages (each housing 5 rats) identified by ear puncture. They were obtained from the Animal Breeding Laboratory Centre of the College of Medicine. The rats 6-8 weeks old weighing between 90-140 g were housed in standard well ventilated cages in the rat control room. They were allowed free access to laboratory chow and distilled water ad libitum. The temperature range was between $26-280 \mathrm{C}$; relative humidity $50-55 \%$ and were exposed to $12 \mathrm{~h}$ light and $12 \mathrm{~h}$ dark cycle. They were left to adapt to laboratory conditions for 2 weeks before initiation of the experiment and were re-weighed. Vaginal smears were taken daily between 8.00-9.00am. Only 4 day cycling rats were used for the experiment.

Pharmarcognosy of Abrus precatorius seeds extract. The dried seeds of $A P$ were procured from Mushin market, a local market in Lagos State, Nigeria. They were taken for identified and authenticated in the Department of Botany, Faculty of Science University of Lagos (UNILAG), Nigeria. The voucher specimens (no. 107858) were subsequently deposited in the departmental herbarium. Methanolic extraction of the seeds of $A P$ was done as previously described by Monago \& Alumanah (2005), with slight modifications. AP seeds (100g) were extracted with $95 \% \mathrm{w} /$ w methanol in the Pharmacognosy Department, Faculty of Pharmacy UNILAG. The extract was stored in sterile bottles and preserved in the refrigerator at $-40^{\circ} \mathrm{C}$ until needed.

Investigational design, necropsy schedule and histological studies. The protocols in this study kowtowed guiding ethics for research involving animals as recommended by the Declaration of Helsinki and the Guiding Principles in the Care and (World Medical Association \& American Physiological Society, 2002) and were approved by the Departmental Committee on the Use and Care of Animals in conformity with international acceptable standards.

The rats were divided into the three groups: treatment, control and reversibility groups; designated IAP50 IIH20 \&
IIIREV. The animal population distributions in the groups were 10, 20 and 10 respectively. The rats in the treatment (IAP50) and reversibility (IIIREV) groups were administered oral $A P$ seed extract at dose $50 \mathrm{mg} / \mathrm{kg}$ body weight (b.w). The duration of treatment was for 32 days ( 8 cycles). The animals in the control group (IIH20) were given an equal volume of distilled water on the same days. The rats in the groups were weighed every three days during this period. At the end of this period, all the animals in Group IAP50 and half (i.e. 10 rats) in Group IIH20 were sacrificed under light chloroform anesthesia. A laparotomy done and the ovaries, uteri and oviducts harvested for microscopic studies. The effect of withdrawal of the extract was studied in rats in Reversibility group (IIIREV). They were weaned from the extract and together with the rats in second half (i.e. the other 10 rats) group IIH20 were fed distilled water for another 32 days ( 8 cycles). The animals were sacrificed at the end of this period and target tissues processed similarly.

The harvested organs from the sacrificed rats were carefully dissected out, trimmed of fat and connective tissue. The tissues were processed by the method described below with slight modification (Humason, 1979). The trend concerned in tissue processing includes fixation, dehydration, clearing, infiltration, embedding, blocking, sectioning, and staining. The tissues were fixed in $10 \%$ formal saline, and then conveyed to a varying series of ethanol $(50 \%, 70 \%$, $90 \%$, absolute alcohol), then cleared in xylene. Once cleared, the tissues were infiltrated in molten paraffin wax in the oven at $58^{\circ} \mathrm{C}$. Three modifications of molten paraffin wax at one-hour intervals were made, after which the tissues were embedded in wax and made into blocks of wax. Microtome whose sectioning size knob was adjusted to six microns was then used to section the block, fixed on clean slides and later stained with haematoxylin and eosin.

\section{RESULTS AND DISCUSSION}

Routine light microscopy of the ovary, uterine tube and uterus revealed obvious tissue modifications. The sections of ovaries from control rats showed normal ovoid shape with follicles in different stages of development and densely cellular stroma (Fig. 1a). This is in consonance with findings in ovaries of normal rat species as described by (Young \& Heath, 2000; Junquiera \& Carneiro, 2005). This shows sections from control rats displayed consistently good histological preservation indicating that the fixation method and tissue processing were optimal. The ovaries of the treated rats however, showed varying effects (Figure 1b). There were reduction in the size, large follicular distension and extensive stromal necrosis with a moderately reduced cellularity. Fewer 

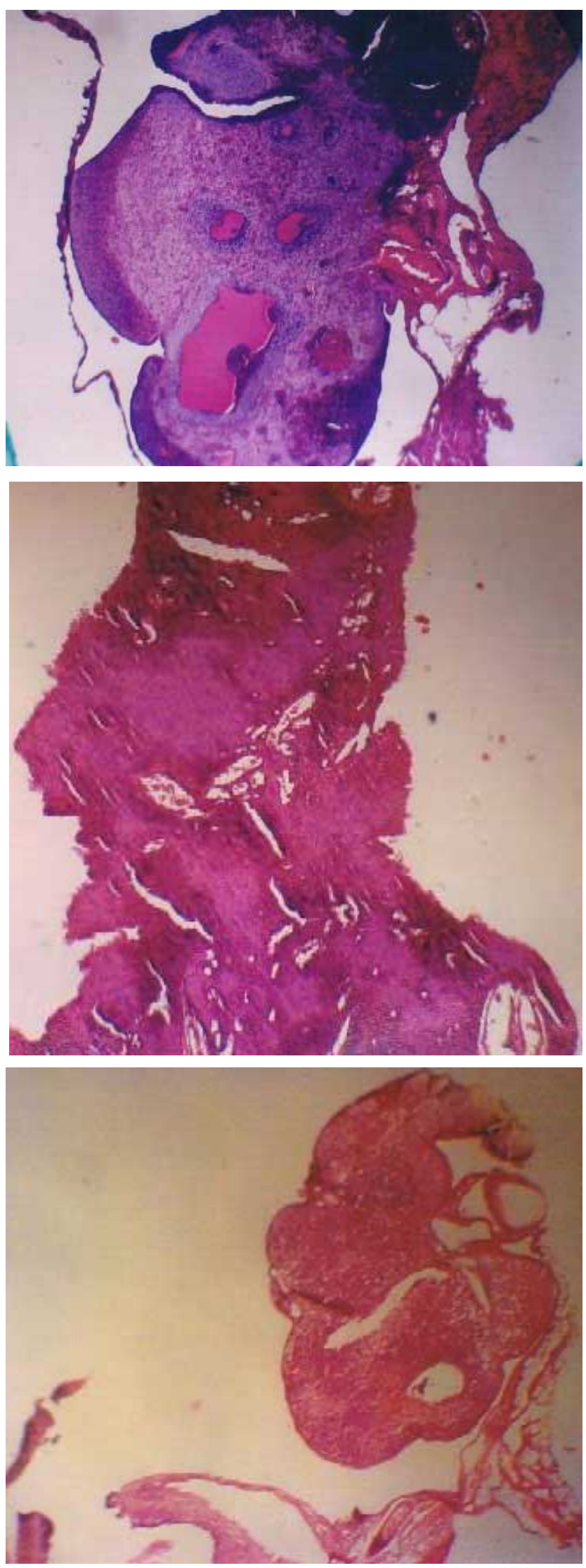

1410 vessels were seen in the treated ovary but no haemorrhagic spots were present (Fig. 1b). The ovarian sections from treated rats sacrificed on the morning of proestrous $(9.00$ am) exhibited normal ovoid shape similar to that of control. However, the follicles were fewer and were located at the periphery with no primary oocyte compared to control. Histological examination of reversal ovary revealed an ovary whose size is similar to that of the control (Fig. 1c). Also observed were clear follicular spaces, distorted granulosa cells, reduced cellularity within the stroma and few blood vessels with no haemorrhagic spots. There was an extensive fatty change in the reversal ovary compared to control (Figs. 1a and 1c).

The uterine tubes of the control rats exhibited branched mucosal folds in the mucosa (Fig. 2a) similar to those described by Saladin (1998) and Junqueira \& Carneiro. Conversely the sections of the uterine tubes of extract treated rats revealed marked mucosal reduction compared to control (Fig. 2b). The reversal group also showed labyrinthine folds in the mucosa as in the control but with fatty degeneration (Fig. 2c).

The uteri of the control rats exhibited a well differentiated serosa, muscularis and endometrial layers. Many well developed glands were also present and the stroma was densely cellular (Fig. 3a). This is similar to those described by (Young \& Heath, 2000). On the other hand, treated rats showed a marked difference in the general histological structure (Fig. 3b). These changes ranged from moderate cellularity to glandular distortion as well as necrosis. The thickness of the endometrial layers was also reduced when compared to control (Fig. 3b). Histological examination of the uterus rats treated in the morning of proestrous exhibited moderate cellularity, dilated vessels, slight reduction in the number of well developed glands and reduction in the layer of endometrial thickness compared to control (Fig. 3c). The histological section of reversal experimental rats were revealed moderate cellularity, newly formed glands, and mild fatty change compared to control (Fig. 4).

The reduction in size in the 32 days ( 8 cycles) treated ovary indicated a decrease in the activity of the stroma, the follicle and the corpus luteum. This decrease may be due to non availability of gonadotropic or steroidal hormones or both (Shivalingappa et al., 2002). Increase in the number

Fig. 1. Photomicrographs of ovarian histology of (a) control rat; (b) rat treated with $A P(50 \mathrm{mg} / \mathrm{kg}$ b.w $)$ extract for 32 days ( 8 cycles) (c) withdrawal experimental rats. HE x40. 

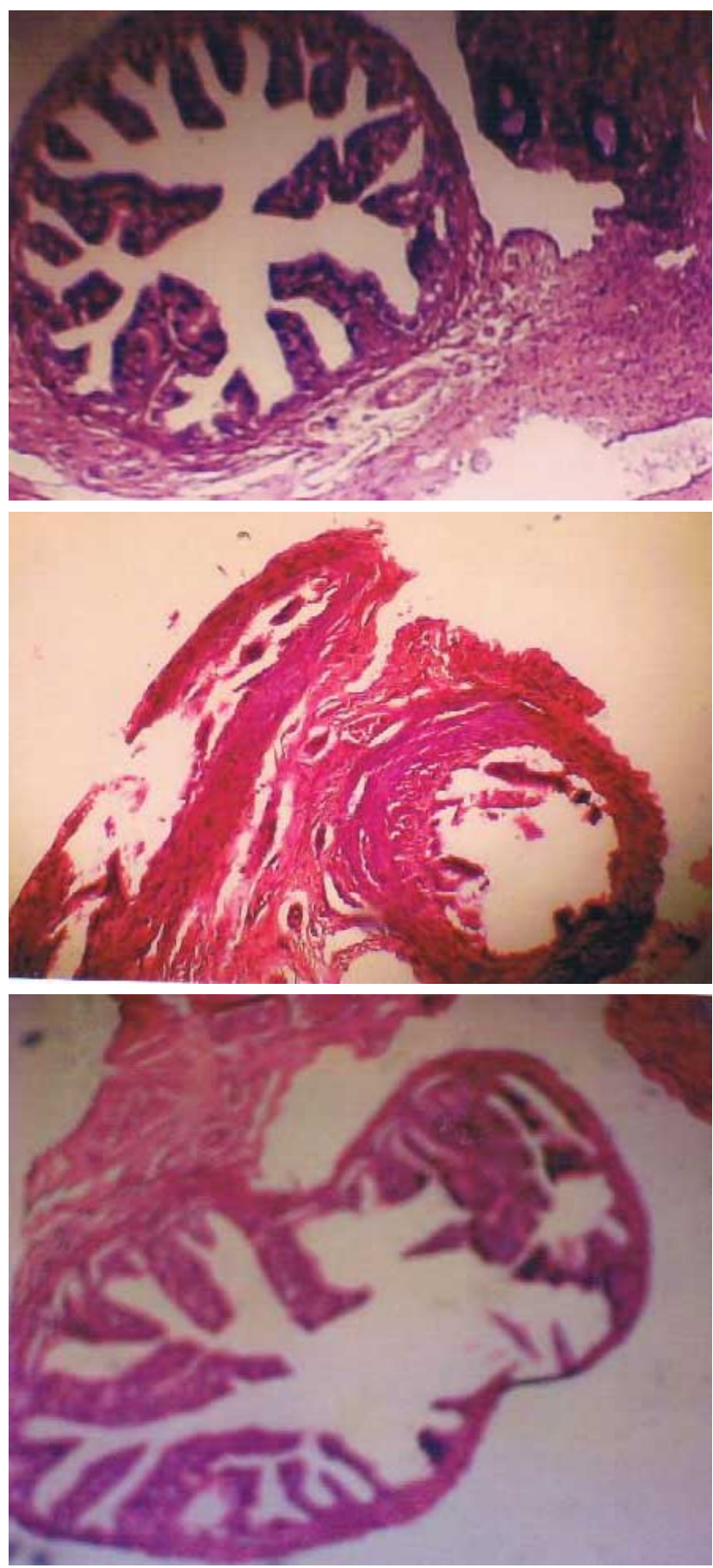

Fig. 2. Photomicrographs of uterine tubes histology of (a) control rat; (b) rat treated with $A P(50 \mathrm{mg} / \mathrm{kg} \mathrm{b.w})$ extract for 32 days $(8$ cycles) (c) withdrawal experimental rats. Stained with HE x 40.

of atretic follicles in the ovary indicated that the extract promoted degeneration of preovulatory follicles (Tilly et al., 1992). This is in agreement with a previous report by Khan et al. (1993) on oxytoxic activity of globulin of $A P$ seed in
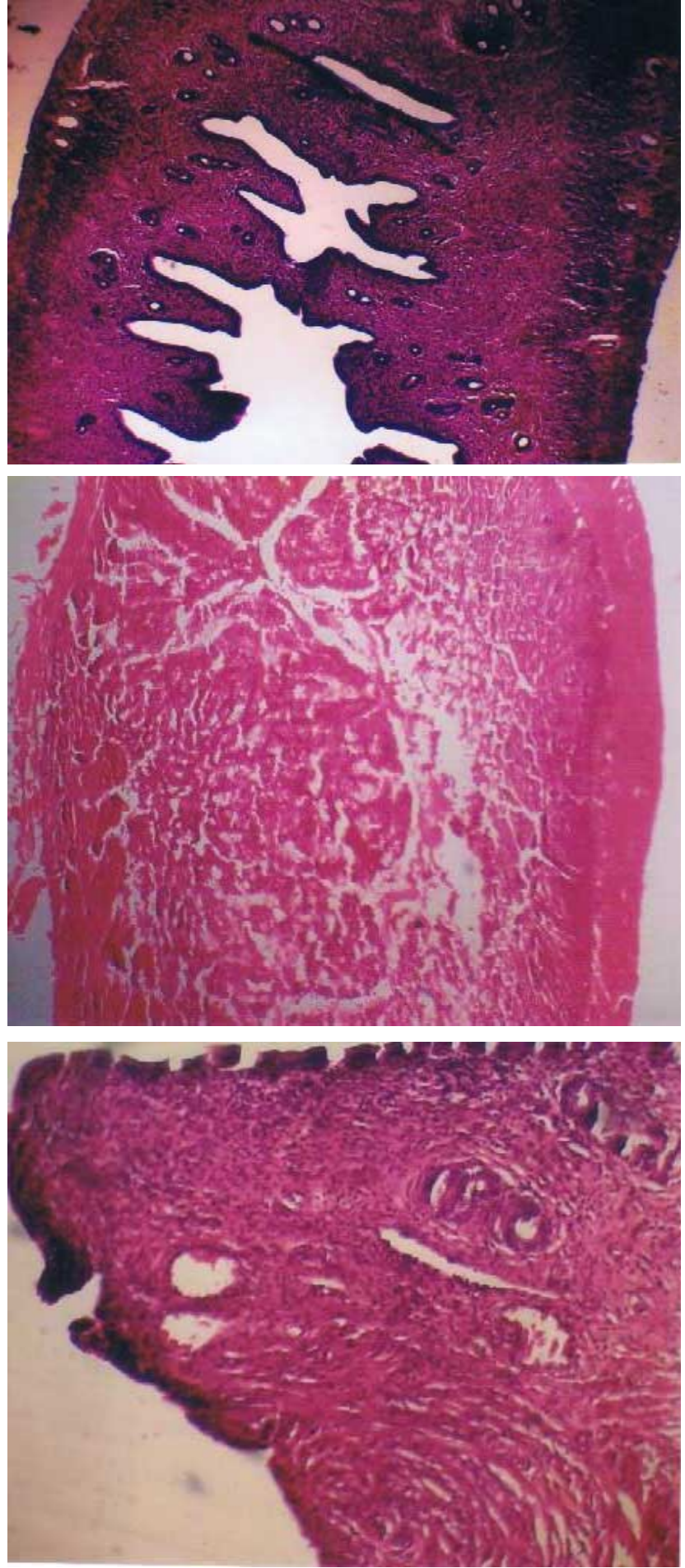

Fig. 3. Photomicrographs of uterus histology (a) control rat; (b) rat treated with $A P(50 \mathrm{mg} / \mathrm{kg}$ b.w) extract for 32 days ( 8 cycles) (c) rat treated with $A P(50 \mathrm{mg} / \mathrm{kg}$ b.w) extract for 1 day (on proestrous). HE $x 40$.

rabbit and Koneri et al. (2006) on anti ovulatory potentials of Momordica cymbalaria root extract on rats. Their 


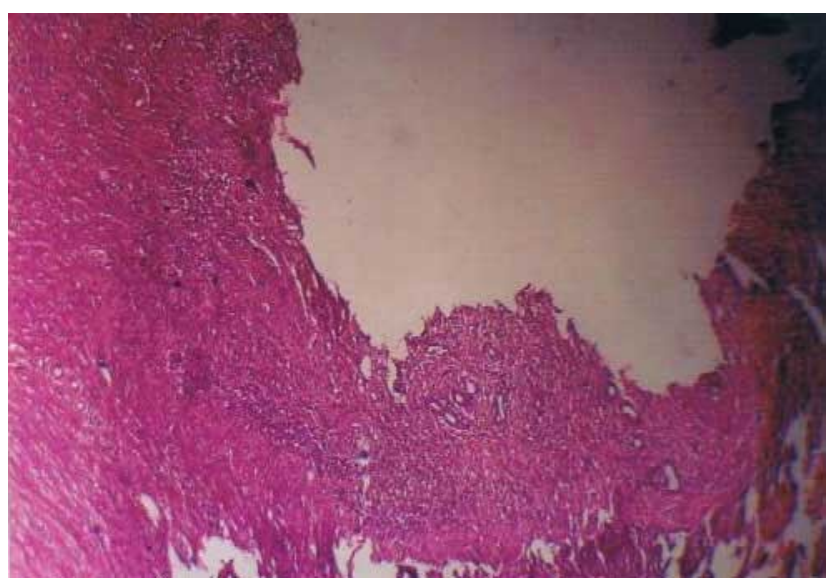

Fig. 4. Photomicrographs of uterine histology withdrawal experiment. Stained with Heamatoxylen and Eosin at Magnification X40.

histological findings agreed with increased in the number of atretic follicle in rats treated with extracts. Histological sections of the oviducts essentially showed affectation of the 32 days treated and withdrawal effects rats which revealed marked mucosal reduction and fatty change respectively. Histological sections of the uterus showed decreased endometrial thickness in all the treated rats compared to control.

In conclusion the present study has provided qualitative histo-morphological evidence that $A P$ seed extract at dose $50 \mathrm{mg} / \mathrm{kg}$ b.w was capable of inducing noteworthy alterations in targeted female reproductive organs. This cytotoxic effect may be reversible after discontinuation of the extract. This study has an enormous potential of developing a female contraceptive. Our findings show that $A P$-induced toxicity is an excellent animal model for the study of fertility and infertility.

\section{ACKNOWLEDGEMENTS}

Special thanks to Mr. Adeleke (Pharmacognosy Department Faculty of Pharmacy University of Lagos Nigeria) for his help with the preparation of the herbal decoction and also for his support for this work. We wish also to acknowledge Prof. J. Olowokudejo (Taxonomist, Botany Department of the University of Lagos Nigeria) for his identification and authentication of the plant.

OKOKO, I. E. \& YAMA, O. E. Variaciones citoarquitectónicas en el ovario, oviducto y útero después del gavage intragástrico de Abrus precatorius Linn en ratas albinas.Int. J. Morphol., 29(4):1408-1413, 2011.

RESUMEN: En los países en desarrollo, las hierbas medicinales siguen siendo de gran importancia y de fácil utilización. Numerosas plantas se han utilizado históricamente para reducir la fertilidad y la investigación científica moderna ha confirmado el efecto anti-fertilidad en algunas de las hierbas estudiadas. Para investigar los efectos de Abrus precatorius (AP) sobre la histología del ovario, oviducto y útero de ratas Sprague-Dawley (SD), fueron utilizadas un total de 40 ratas SD hembras de 6-8 semanas de edad en el día 4 del ciclo. Se dividieron en grupos de tratamiento, control y reversibilidad. Los grupos de tratamiento y reversibilidad se alimentaron por vía oral con el extracto de semilla de AP (50 mg/kg de peso corporal) durante 32 días. Una fracción de las ratas del grupo de reversibilidad se trató con agua destilada durante otros 32 días. El grupo de control se utilizó para comparar los eventos en los otros grupos. Al finalizar el periodo experimental los animales fueron sacrificados bajo anestesia con cloroformo. Los ovarios, útero y los oviductos fueron procesados para los estudios microscópicos. Al comparar las secciones de control histológico con los grupos tratados, los ovarios mostraron disminución del tamaño, gran distensión folicular y necrosis estromal extensa con celularidad comprometida. Las tubas uterinas revelaron una reducción apreciable de la mucosa. El útero mostró una reducción de grosor en la capa endometrial. Por otra parte, las secciones del grupo de ratas experimentales con reversibilidad fueron comparables a los de control. Las ratas tratadas con extracto de semilla de $A P$ en dosis de $50 \mathrm{mg} / \mathrm{kg}$ de peso corporal indujeron alteraciones reversibles en los ovarios, oviductos y úteros en ratas SD.

PALABRAS CLAVE: Abrus precatorius; Ratas Sprague-Dawley; Ovarios; Úteros; Oviductos.

\section{REFERENCES}

Armstrong, W. P. Botanical Jewelry: Necklaces \& Bracelets Made From Plants. Wayne's Word, 9(1), 2000. Available in: http:// waynesword.palomar.edu/ww0901.htm

Budavari, S. The Merck Index: An encylopedia of chemicals, drugs, and biologicals. $10^{\text {th }}$ ed. Rahway, New Jersey, Merck \& Co. Inc., 1989. pp.15-8, 29-32.
Deepak, A. The important Indian medicinal plants for curing various disorders with special reference to Sciatica, 2003. Available in: http://www.selfgrowth.com/articles/Acharyal4.html

Fernando, C. Poisoning due to Abrus precatorius (jequirity bean). Anaesthesia, 56(12):1178-80, 2001. 
Humason, G. L. Animal Tissue Techniques. San Francisco and London, Freeman and Co., 1979. pp.3-39. Available in: http:/ /openlibrary.org/books/OL23277361 M/ Animal_tissue_techniques

Junqueira, L. C. \& Carneiro, J. Basic Histology - Text and Atlas. 11th ed. New York, McGraw-Hill, 2005. pp.449-67.

Khan, F. Z.; Saeed, M. A. \& Ahmad, E. Oxytocic activity and toxic effects of globulins of Abrus seeds (scarlet variety) in rabbits. J. Islam Acad. Sci., 6(2):108-13, 1993.

Koneri, R.; Balaraman, R. \& Saraswah, C. D. Antiovulatory and abortifacient potential of the ethanolic extract of roots of Momordica cymbalaria Fenzl in rats. Indian J. Pharmacol., 38(2):111-4, 2006.

Limmatvapirat, C.; Sirisopanaporn, S. \& Kittakoop, P. Antitubercular and antiplasmodial constituents of Abrus precatorius. Planta Med., 70(3):276-8, 2004.

Monago, C. C. \& Alumanah, E. O. Antidiabetic effect of chloroform-methanol extract of Abrus precatorius Linn seed in Alloxan Diabetic Rabbit. J. Appl. Sci. Environ. Manag., 9(1):85-8, 2005

Nath, D.; Sethi, N.; Singh, R. K. \& Jain, A. K. Commonly used Indian abortifacient plants with special reference to their teratogenic effects in rats. J. Ethnopharmacol., 36(2):147-54, 1992.

Okoko, I. I.; Osinubi, A. A.; Olabiyi, O. O.; Kusemiju, T. O.; Noronha, C. C. \& Okanlawon, A. O. Antiovulatory and antiimplantation potential of the methanolic extract of seeds of Abrus precatorius in the rat. Endocr. Pract., 16(4):554-60, 2010 .

Olsnes, S. The history of ricin, abrin and related toxins. Toxicon, 44(4):361-70, 2004

Rajaram, N. \& Janardhanan, K. The chemical composition and nutritional potential of the tribal pulse, Abrus precatorius $L$. Plant Foods Hum. Nutr., 42(4):285-90, 1992.

Ratnasooriya, W. D.; Amarasekera, A. S.; Perera, N. S. \& Premakumara, G. A. Sperm antimotility properties of a seed extract of Abrus precatorius. J. Ethnopharmacol., 33(1-2):8590, 1991

Saladin, K. S. Anatomy and Physiology: The Unity of Form and Function. Boston, WCB McGraw Hill, 1998. pp.100-6.

Shivalingappa, H.; Satyanarayan, N. D.; Purohit, M. G., Sharanabasappa, A. \& Patil, S. B. Effect of ethanol extract of Rivea hypocrateriformis on the estrous cycle of the rat. $J$. Ethnopharmacol., 82(1):11-7, 2002.
Sinha, R. Post-testicular antifertility effects of Abrus precatorius seed extract in albino rats. J. Ethnopharmacol., 28(2):173-81, 1990.

Sinha, S. \& Mathur, R. S. Effect of steroidal fraction of seeds of Abrus precatorius Linn. on rat testis. Indian J. Exp. Biol., 28(8):752-6, 1990.

Taylor, L. Tropical Plant Database. Austin, Raintree Nutrition Inc., 2002. Available in: http://www.rain-tree.com/abrus.htm

Tilly, J. L.; Billig, H.; Kowalski, K. I. \& Hsueh, A. J. Epidermal growth factor and basic fibroblast growth factor suppress the spontaneous onset of apoptosis in cultured rat ovarian granulosa cells and follicles by a tyrosine kinase-dependent mechanism. Mol. Endocrinol., 6(11):1942-50, 1992.

Young, B. \& Heath, J. W. Wheater's Functional Histology : A Text and Colour Atlas. Edinburgh, Churchill Livingstone, 2000. pp.342-52.

World Medical Association \& American Physiological Society. Guiding principles for research involving animals and human beings. Am. J. Physiol. Regul. Integr. Comp. Physiol., 283(2):R281-3, 2002.

Correspondence to:

Dr. Oshiozokhai Eboetse Yama (MBBS, MSc, PhD.)

Department of Anatomy

College of Medicine of the University of Lagos

P.M.B. 12003, Lagos

NIGERIA

Phone: +2348098321251

E-mail: dro_yama@yahoo.com

Received: 27-06-2011

Accepted: 17-08-2011 